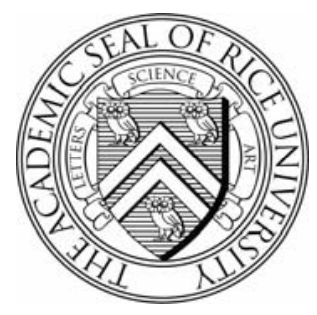

The James A. Baker III InStitute for Public Policy RICE UNIVERSITY

\title{
THE PROPERTY TAX AS A CAPITAL TAX: A ROOM WITH THREE VIEWS
}

BY

GeOrge R. ZODROW, PHD

PROFESSOR OF ECONOMICS AND RICE SCHOLAR

TAX AND EXPENDITURE POLICY PROGRAM

JAMES A. BAKER III INSTITUTE FOR PUBLIC POLICY

RICE UNIVERSITY 
The Property Tax as a Capital Tax: A Room with Three Views

THESE PAPERS WERE WRITTEN BY A RESEARCHER (OR RESEARCHERS) WHO PARTICIPATED IN A BAKER INSTITUTE RESEARCH PROJECT. WHEREVER FEASIBLE, THESE PAPERS ARE REVIEWED BY OUTSIDE EXPERTS BEFORE THEY ARE RELEASED. HOWEVER, THE RESEARCH AND VIEWS EXPRESSED IN THESE PAPERS ARE THOSE OF THE INDIVIDUAL RESEARCHER(S), AND DO NOT NECESSARILY REPRESENT THE VIEWS OF THE JAMES A. BAKER III INSTITUTE FOR PUBLIC POLICY.

THIS PAPER IS AN UPDATED VERSION OF A PAPER THAT FIRST APPEARED IN THE MARCH 2001 ISSUE OF THE NATIONAL TAX JOURNAL, VOlume 54, PAGES 139-156. THE AUTHOR WOULD LIKE TO THANK PETER MIESZKOWSKI, JOHN YINGER AND DOUGLAS HOLTZ-EAKIN FOR HELPFUL COMMENTS.

C 2007 BY GEORGE R. ZODROW, PHD

THIS MATERIAL MAY BE QUOTED OR REPRODUCED WITHOUT PRIOR PERMISSION, PROVIDED APPROPRIATE CREDIT IS GIVEN TO THE AUTHOR AND THE JAMES A. BAKER III INSTITUTE FOR PUBLIC POLICY. 


\section{The Property Tax as a Capital Tax: A Room with Three Views}

\section{Introduction}

The property tax has long been the major source of own-revenue at the local government level, and a huge academic literature has investigated the economic effects of this widely used tax; Mieszkowski and Zodrow (1989) and Ladd (1998) provide reviews of this literature. Nevertheless, despite all this attention, the incidence of the property tax - the critical issue of who ultimately bears the burden of the tax - is still one of the more controversial and more interesting issues in state and local public finance. Three alternative views of the incidence of the tax have appeared in the literature - the "traditional view" which argues that the property tax is fully shifted forward to consumers in the form of higher housing prices, the "benefit view" which concludes that the property tax is simply a payment for local public services received, and the so-called "new view" of the property tax which argues that it is a distortionary tax on the use of capital within a local jurisdiction. This article reviews the ongoing debate regarding the incidence of the property tax, including both the theoretical underpinnings of the various views and the empirical evidence that might be used to differentiate among them. ${ }^{1}$

The central theme of the article is that each of the three views can - to a considerable but certainly not complete extent - be illuminated by reference to model of the property tax as a capital tax that underlies the new view. (Given that the "new" view is now approaching its thirtieth birthday, I shall - after consultation with my frequent co-author and the originator of the new view, Peter Mieszkowski - refer to it as the “capital tax” view.) In particular, as has long been understood, the traditional view can be shown to be a special case of the capital tax view. Moreover, as stressed by Zodrow (2000), when considered from the perspective of a single taxing local jurisdiction, the capital tax view implies that local use of the property tax is characterized by many of the features associated with the benefit view. However, the essential difference between the two views still remains - the capital tax view implies that the property tax is a distortionary tax on the use of capital within a jurisdiction, while the benefit view implies that the tax is a non-distortionary user charge for public services received. Nevertheless, another

1 In general, the discussion will follow the bulk of the academic literature and focus on the capital portion of the residential property tax. 
The Property Tax as a Capital Tax: A Room with Three Views

central theme of the article is that the two approaches are sufficiently similar that it is quite difficult to distinguish between them in empirical research.

\section{The Three Views of the Property Tax}

Each of the three views of the property tax has a long history. The following discussion summarizes this history and provides a brief outline of the derivations and the primary implications of the three views.

\section{The Traditional View}

The traditional view dates back to Simon (1943) and Netzer (1966), who took a partial equilibrium approach to analyzing the tax, focusing on the effects of increasing the tax in a local housing market. From this perspective, one can make the standard “open economy” assumption that the national return to capital is fixed. This in turn implies that local capital bears none of the local property tax, as capital in the long run migrates from the jurisdiction until the local aftertax return to capital equals the national value. The burden of the tax is thus borne by local factors and/or consumers, and the traditional view holds that this entire burden is borne by local housing consumers in the form of higher housing prices. The traditional view thus implies that the property tax inefficiently reduces the size of the local housing stock and that its burden is borne in proportion to housing consumption (and is thus somewhat regressive or roughly proportional with respect to lifetime income).

\section{The Benefit View}

A second popular theory is the benefit view of the property tax. It was developed initially by Hamilton (1975, 1976a), Fischel (1975) and White (1975), and is reviewed in Hamilton (1983) and Fischel (forthcoming, and in this issue of the NTA Forum). This view is an important extension of the renowned Tiebout (1956) model of local government, which argues that consumer mobility ("voting with the feet" for alternative local tax and expenditure combinations) and interjurisdictional competition in the provision of local public services are, under certain conditions sufficient to ensure efficiency of resource allocation in the local public sector. Tiebout ignored local property taxation and instead assumed the existence of benefit taxes in the form of head taxes. However, in his important contributions to the literature, Hamilton 


\section{The Property Tax as a Capital Tax: A Room with Three Views}

developed the conditions under which the property tax can be converted into the head tax assumed by Tiebout.

Following Tiebout, Hamilton assumed that individuals are sorted into local jurisdictions according to their demands for local public services, and that there are enough local taxexpenditure packages to accommodate all tastes. In addition, Hamilton (1975) assumed that local jurisdictions are also homogeneous with respect to house values, and that there are enough jurisdictions to accommodate all desired housing/government service packages. Finally, Hamilton assumed the existence of binding zoning constraints that established a minimum house value for each community. Under these circumstances, individuals were precluded from purchasing homes with a value below the minimum and thus "free riding" on their neighbors in the sense of enjoying local public services without paying at least the taxes associated with the minimum value home. Moreover, individuals would never purchase a home with a value greater than the minimum house value established by the zoning constraint, as doing so would imply subsidizing the public service consumption of their neighbors; such individuals would instead move to a community where the demands for housing and public services exactly matched their own. Under such circumstances, all individuals in a given community pay exactly the same property tax, which functions precisely as a benefit tax.

Hamilton (1976a) extended this model to the more realistic case in which house values are heterogeneous. In this model, Hamilton assumes that all communities are fully developed, effectively precluding changes in the housing stock in response to changes in the level of property taxation. In addition, he assumed that even though some communities were heterogeneous with respect to housing consumption, communities that were homogeneous with respect to both demands for public services and housing were available as well. This assumption implies that no individuals would be willing to pay any property taxes in excess of benefits received, since the option of a fully homogeneous community is always available. Under these circumstances, Hamilton shows that "perfect capitalization" converts the property tax into a benefit tax, at least in long run equilibrium (but not at the time that a tax change occurs and is capitalized into property values). This result obtains because a relatively expensive home must sell at a discount equal to its "fiscal differential” or the present value of all future taxes in excess of benefits received, while a relatively inexpensive home sells at a premium reflecting its fiscal 


\section{The Property Tax as a Capital Tax: A Room with Three Views}

differential, which in this case is the present value of all future benefits in excess of future taxes. (In the latter case, individuals are willing to pay the premium since their only alternative is a homogeneous community with low house values and low public services.)

Hamilton's work has been extended by Fischel (1985, 1995), who argues that zoning ordinances, defined comprehensively to include a wide variety of land use regulations, are sufficiently restrictive to convert the property tax into a benefit tax in the manner envisioned by Hamilton (1975). He stresses that zoning ordinances are not limited to specifying minimum lot sizes (and one home per lot), but can encompass many other types of land use regulations. More recently, Fischel (forthcoming) has argued that a wide variety of empirical studies, especially the comprehensive work of Yinger, Bloom, Boersch-Supan and Ladd (1988), have found evidence that property taxes and local public service expenditures are capitalized into house values as predicted by the Hamilton (1976a) model. He argues that fiscal “capitalization is everywhere” and that the existence of such capitalization is sufficient to make the property tax a benefit tax at the local level.

The implications of the benefit view are striking. First, the property tax is effectively a user charge that is paid in exchange for the benefits of local public service. It is thus a nondistortionary tax. Second, as a benefit tax, the property tax has no effects on the distribution of income.

\section{The Capital Tax View}

Finally, the capital tax view (that is, the "new" view) of the property tax, first developed by Mieszkowski (1972), subsequently extended by Zodrow and Mieszkowski (1983, 1986b) and reviewed in Zodrow (forthcoming), argues that the property tax is a distortionary tax on the local use of capital, which results in a misallocation of the national capital stock across local jurisdictions. Mieszkowski (1972) stressed that the partial equilibrium analyses of the property tax that characterized the traditional view were highly misleading as they ignored the fact that the property tax was used by virtually all local jurisdictions and applied to a large fraction of the capital stock (including most non-residential capital). Adapting the Harberger (1962) general equilibrium model of tax incidence to the analysis of the property tax, he modeled the economy as having a fixed national capital stock and two types of local jurisdictions - those 


\section{The Property Tax as a Capital Tax: A Room with Three Views}

characterized by "high" tax rates and those characterized by "low" tax rates. In this context, Mieszkowski showed that property tax rates that exceed the national average drive capital out of the high-tax jurisdiction into a relatively low-tax jurisdiction, with opposing effects occurring in relatively low tax jurisdictions. ${ }^{2}$ Property tax differentials thus result in an inefficient misallocation of capital across jurisdictions. In terms of incidence, the "average burden” of all of the property taxes imposed across the nation - known as the "profits tax effect" of the tax - is borne by capital owners generally. In marked contrast to the other two views, this profits tax effect implies that the property tax is relatively progressive (with respect to annual income) and is thus a relatively progressive element of the national tax structure. In addition, Mieszkowski stressed that property tax differentials about the national average result in "excise tax effects" in the form of housing and commodity price increases and wage and land price declines in relatively high tax jurisdictions; these effects are accompanied by offsetting housing and commodity price declines and wage and land price increases in relatively low tax jurisdictions. These roughly symmetric excise tax effects tend to cancel, so that from a national perspective their distributional effects are secondary; that is, the profits tax effect is the primary factor affecting the distribution of the tax burden under the capital tax view.

This short description of the three views of the property tax obviously only provides an outline of their main tenets and derivations. Nevertheless, the analysis makes clear that the choice between the three alternative views is an important issue, as their implications for both the efficiency of resource allocation to the local public sector and the distribution of the burden of the property tax are quite different.

\section{The Capital Tax View: A Theory (Partially) Encompassing All Three Views}

As suggested in the introduction, the capital tax view can be described as being sufficiently general to encompass much, although not all, of the competing two views. In the case of the traditional view, this description is complete, as the traditional view is simply a special case of

2 In addition, local concerns about the extent to which use of the property tax may drive capital out of a jurisdiction creates a tendency for local governments to choose an inefficiently low level of public services; this point was developed Zodrow and Mieszkowski (1986b) and Wilson (1986), and the associated literature is reviewed in Wilson (1999). 


\section{The Property Tax as a Capital Tax: A Room with Three Views}

the capital tax view. Specifically, the traditional view can be interpreted as focusing exclusively on the "excise tax effects" of the capital tax view, while — as is standard for such a partial equilibrium analysis - neglecting the general equilibrium effects of the tax which in this case are its "profits tax" components. In particular, as shown by Wildasin (1986) within the context of a model that is consistent with the capital tax view, the excise tax effects of an increase in the property tax by a single jurisdiction will be fully reflected in higher housing prices only under special circumstances - specifically, when the land supply is fixed and the extent to which consumers can substitute between housing and other goods is equal to the extent to which producers can substitute between capital and land in the production of housing. ${ }^{3}$ More generally, as described in Mieszkowski's original derivation, the excise tax effects of a property tax increase in a single jurisdiction are borne in some combination by housing consumers and the owners of labor and land in the taxing jurisdiction; in particular, backward shifting of the tax onto local landowners is more likely if individuals can move easily across competing jurisdictions.

The extent to which the capital tax view encompasses the benefit view is less complete and less transparent. The basic points can be seen by examining two alternative derivations of the capital tax view. First, Zodrow and Mieszkowski (1986a) extended the original Mieszkowski (1972) derivation to include many of the aspects of local government use of the property tax stressed by proponents of the benefit view. ${ }^{4}$ In particular, the Zodrow-Mieszkowski model explicitly considered interjurisdictional competition, individual utility functions that include varying tastes for local public services, segregation into differing communities according to individual tastes for local public services, and a simple form of land use zoning; all of these factors were ignored in the original Mieszkowski derivation. They show that adding all of these "benefit-view-type" features to the capital tax view model does not change its basic results, as long as (1) capital is mobile across jurisdictions in response to interjurisdictional property tax differentials, and (2) capital is fixed in total supply at the national level. Under these circumstances, the incidence of

3 More formally, the elasticity of substitution in consumption between housing and other goods in the individual utility function equals the elasticity of substitution in production between capital and land in the housing production function. 


\section{The Property Tax as a Capital Tax: A Room with Three Views}

the property tax is still determined by its profits tax and excise tax effects, despite the various benefit view features that characterize the model.

The second alternative derivation of the capital tax view focuses on a general equilibrium analysis of the incidence of tax changes initiated by a single independent jurisdiction. At first glance, it might appear that the capital tax view is irrelevant for such a tax increase, as models of tax changes by such a "small open economy" typically assume that it faces an infinitely elastic supply of capital so that its policies cannot affect the after-tax return to capital. However, Zodrow and Mieszkowski (1983), following the work of Brown (1924) and Bradford (1978), demonstrate that such a view can be misleading; in particular, the capital tax view of the property tax can in fact be derived in such a context as well. ${ }^{5}$ Specifically, even though the outflow of capital caused by an increase in the property tax by a small local jurisdiction is small, it will depress the overall return to capital very slightly. Although the taxing jurisdiction can reasonably neglect this small effect, it naturally affects a very large capital stock, and the revenue raised by the small taxing jurisdiction is also quite small. Mieszkowski and Zodrow show that under certain circumstances the overall reduction in national capital income precisely equals the amount of revenue raised by the taxing jurisdiction — that is, capital bears the full burden of the tax. This of course is simply the profits tax effect of the capital tax view, as applied to an increase in the property tax by a single small local jurisdiction.

Moreover, this analysis is entirely consistent with the standard analysis of the incidence of a tax on capital by a small taxing jurisdiction, which concludes that the tax is borne by local factors of production or local consumers. ${ }^{6}$ This effect occurs simultaneously, as the tax-induced outflow of capital from the taxing jurisdiction implies lower returns to relatively immobile factors such as local land and labor and/or higher prices to local consumers. Indeed, for a sufficiently small

\footnotetext{
4 This paper was partially a response to Aaron (1975, p. 42) who argued in his often-cited survey of the property tax literature that "the theoretical foundations of the new view are incomplete."

5 See also the excellent analysis by Lin (1986) and, in the context of state corporate tax on capital, Mieszkowski and Zodrow (1985).

6 This is a standard "open economy" result; see for example Kotlikoff and Summers (1987). See also McLure (1977) who stresses the differences between the national effects of the property tax and its effects when imposed by a single taxing jurisdiction.
} 


\section{The Property Tax as a Capital Tax: A Room with Three Views}

economy - a condition which would describe virtually all local jurisdictions - Kotlikoff and Summers (1987) show that the tax burden borne by local factors is roughly equal to the total burden of the tax. The case in which the entire tax burden is shifted forward to consumers of course corresponds to the "traditional view" of the incidence of the property tax. More generally, the local burden of the tax is shared between consumers and the owners of local factors.

The critical point here is that under the capital tax view — just as under the benefit view — there is a close link between local public services and the burden of the property tax, as the burden of financing local expenditures largely falls on local factor owners and local consumers in the taxing jurisdiction. Indeed, to the extent that local landowners (in particular, homeowners) reside in the taxing jurisdiction and increases in consumer prices are limited to goods (including especially housing) that are produced and consumed locally, ${ }^{7}$ this derivation of the capital tax view clearly has a striking benefit view flavor - the burden of increases in local government expenditures financed with increases in the local property tax tends to be borne entirely by local residents. The primary difference between this "benefit view" version of the capital tax view and the actual benefit view is that the mechanism for achieving this result under the former is different than under the latter, as the burden of the tax on local factors and consumers under the capital tax view arises due to the outflow of capital in response to the imposition of the tax.

Note also that the public choice implications of the two views may be similar. Of course, voters are unlikely to perceive the shifting mechanism underlying the "benefit view" version of the capital tax. Nevertheless, if they link property tax paid with services received and perceive that they bear the incidence of the tax, then their voting behavior — as well as the incentives to "free ride” by under-consuming housing — will be similar to that under the benefit view.

Finally, Mieszkowski and Zodrow also show that the burden of the use of the property tax by a single taxing jurisdiction on local factors of production and local consumers is offset by opposing effects on the analogous factors of production and consumers in all of the non-taxing

7 Note that in the standard small open economy model, the possibilities for forward shifting of taxes on exported goods are severely limited by national and international competition, so that local consumers tend to bear almost all of the burden of the tax that is shifted forward in the form of higher consumer prices. 


\section{The Property Tax as a Capital Tax: A Room with Three Views}

jurisdictions. That is, all of these "excise tax" effects tend to cancel in the aggregate, so that from a national perspective the main distributional effect of the use of the property tax by a single taxing jurisdiction is a reduction in the net return to capital; this result obtains despite the fact, stressed by McLure (1977), that the distributional effects of the tax increase are very different from the perspective of the local jurisdiction. ${ }^{8}$ Thus, in an important sense there are two "burdens" of the use of the property tax by a single taxing jurisdiction - (1) the national burden, which is primarily reflected in a reduction in the overall return to capital in the economy, and (2) the local burden, which is borne by local labor and landowners as well as the consumers of locally produced goods, and accompanied by offsetting effects on factors of production and consumers in all other jurisdictions. The existence of these two simultaneous tax burdens is the key factor giving rise to the benefit tax aspect of the capital tax view.

\section{Choosing Among the Three Views}

A wide variety of studies have attempted to find ways to choose among the three views. One approach has been to attack the basic assumptions underlying the views. For example, the derivation of the capital tax view is suspect because it assumes a fixed national capital stock and neglects the adjustment costs involved in reallocating the capital stock in response to a tax increase, while the benefit view assumes the validity of the Tiebout model, which has been

questioned by a number of authors. ${ }^{9}$ However, most of the debate surrounding the incidence of the property tax has assumed the general validity of the underlying theoretical models and focused instead on other issues. I shall follow such an approach for the balance of the article. Moreover, since the traditional view is essentially a special case of the capital tax view, I shall focus on means of differentiating between the benefit and capital tax views. As noted above, a central message of the article is that even though there are fundamental differences between the two views, they are sufficiently similar that it is often difficult to distinguish between them empirically.

8 More recently Ladd (1998, p. 36) has noted that, "from the perspective of the mayor of an individual city, the property tax is reasonably viewed as regressive" to the extent that the mayor focuses only on the effects of the tax in his or her jurisdiction (and consumption of housing declines with income) and ignores the effects of the use of the property tax by other jurisdictions. However, under the capital tax view, the latter factor implies that the tax is progressive from a national perspective. 


\section{The Property Tax as a Capital Tax: A Room with Three Views}

\section{Evidence Supporting the Tiebout Sorting Mechanism}

Since the benefit view is essentially an extension of the Tiebout model, empirical evidence supporting the existence of the Tiebout "sorting" mechanism - under which households tend to be grouped in jurisdictions that are relatively homogeneous with respect to demands for public services - could be interpreted as providing some support for the benefit view. A number of studies provide empirical evidence that the variation in variables that might be taken as proxies for (unobservable) demands for local public services, such as income and housing consumption, is significantly less within communities than across communities. ${ }^{10}$ However, these studies in fact provide little information on the choice between the benefit and capital tax views. For example, Oates (1994) argues that tendencies toward homogeneity are not a very strong test of the Tiebout model, as such tendencies are consistent with other models of locational behavior, especially the bidding and sorting model developed by Ellickson (1971) and Henderson

(1977). ${ }^{11}$ More fundamentally, however, Zodrow and Mieszkowski (1986a) have derived the standard capital tax view results regarding the incidence of the property tax within the context of a model that is characterized by Tiebout sorting of individuals by taste for public services; indeed, in their model, all desired public service/housing demand packages are available and all communities are perfectly homogeneous with respect to both housing and public service demands. Thus, evidence supporting the existence of the Tiebout sorting mechanism does not provide compelling evidence for either the benefit view or the capital tax view.

\section{The Elasticity of Supply of Communities}

The Tiebout (1956) and Hamilton (1975) models assume the existence of a sufficient number of communities to satisfy all the different individual demands for public services, while the Hamilton (1976a) model requires a sufficient number of communities to satisfy all demands for both public services and housing. Unless the number of desired taste combinations is fairly limited, these are rather strong assumptions, especially since the mechanisms for creating new communities in response to demands for particular housing, tax and services packages are costly.

\footnotetext{
9 For example, see Zodrow (1983), Rubinfeld (1987) and Ross and Yinger (2000).

10 See Ross and Yinger (2000) and the references cited therein.

11 See Ross and Yinger (2000) for a recent survey.
} 


\section{The Property Tax as a Capital Tax: A Room with Three Views}

The reasonableness of this assumption has been debated in the literature. Fischel (1995, p. 255), drawing on earlier work (Fischel, 1981) that indicated that 80 percent of the urban population lives in areas that are highly fragmented, argues that the "choice of locality is especially wide” as most individuals live in metropolitan areas that have "scores if not hundreds of local governments.” However, some observers are still skeptical that the stringent Tiebout conditions can be met even in an approximate sense; for example, Rubinfeld (1987, p. 584) stresses that in a Tiebout-Hamilton world, "The necessary number of such communities is likely to be extremely large.” In any case, as above, Zodrow and Mieszkowski (1986a) show that capital tax view results can still be obtained in models that are perfectly homogeneous with respect to both housing demands and tastes for public services, so such homogeneity does not distinguish between the two views.

\section{Zoning Requirements}

To an important extent, the choice between the benefit and capital tax views hinges on whether zoning ordinances are sufficiently restrictive to set the minimum housing level in a community, and whether such restrictions preclude the long run tax-induced changes in the capital stock predicted by the capital tax view. Fischel (1992) provides an extensive list of the types of zoning restrictions that might be encountered — and substituted for one another, depending on the circumstances. These include minimum lot sizes (and one home per lot), setbacks, height restrictions, requirements for off-street parking, restrictions to single family use, minimum square footage, and differential building code requirements, as well as designation of certain areas as off limits for environmental or other reasons and requirements for the provision of infrastructure at the expense of the developer. In addition, Fischel provides a variety of data on the quantitative significance of zoning ordinances, arguing that the practice of zoning is widespread. For example, he notes that the number of general purpose governments that could in principle enact zoning ordinances exceeds 25,000. Moreover, as detailed in Fischel (1985), there is no question that a great deal of time and effort is devoted to zoning, and that the practice of zoning has attracted a great deal of attention in the legal community. Finally, he notes (Fischel 1995, pp. 262-4) that several empirical studies have demonstrated that fiscal factors are important determinants of the nature of zoning decisions. 


\section{The Property Tax as a Capital Tax: A Room with Three Views}

The admittedly widespread prevalence of zoning restrictions of various types, however, does not by itself demonstrate the validity of the benefit view. As stressed by Mieszkowski and Zodrow (1989), the Hamilton (1975) version of the benefit view obtains only if the zoning requirements are binding — it is in this sense that "perfect" zoning is required for the benefit view to be operative. Of course, as noted by Ladd (1998, p. 34) in her recent insightful review of the debate, perfect zoning in all cases would never be expected; rather the issue is whether zoning under the benefit view "sufficiently approximates reality that it becomes useful for making predictions and drawing conclusions." Unfortunately, evidence on the extent to which zoning constraints are binding is extremely difficult to obtain. Ladd notes that "no one would disagree that the property tax would distort decisions about minor expansions and repair that are beyond the purview of the zoning authority but not the tax assessor" - that is, one would not expect the benefit view to be operative at the margin for such changes in the housing capital stock. Similarly, even the most ardent proponents of the benefit view do not assert that it is operative in large and highly heterogeneous urban areas. ${ }^{12}$ But the extent to which zoning constraints are binding in the suburban communities that are the focus of the Tiebout-Hamilton analysis is difficult to determine. Mieszkowski and Zodrow (1989) and Fischel (1992) note the prevalence of communities that are subject to zoning that specifies minimum lot size and/or minimum square footage, but are quite heterogeneous in terms of house value - with many homes considerably larger than that specified by the zoning restrictions. Ross and Yinger (2000) note that many studies have demonstrated considerable income heterogeneity in suburban jurisdictions, which suggests that zoning constraints are typically not binding. They also argue that "zoning tools, such as lot size restrictions and set-back rules, appear far too blunt to control $\mathrm{H}$ (housing) precisely.” Similarly, Rubinfeld (1987, p. 591) concludes that "there is reason to believe that actual zoning policies deviate substantially from the one which transforms a property tax into a head tax.”

\footnotetext{
12 For example, Ladd (1998, p. 34-35) notes that the benefit view is also not likely to obtain in exurban or rural areas, so that under any circumstances for a "significant proportion of the U.S. population, the property tax is not appropriately viewed as a benefit tax." Fischel (1995) agrees with this assessment and describes empirical evidence that demonstrates a variety of differences across suburban and central city communities which suggests that the assumptions underlying the benefit view are satisfied only in the suburbs.
} 


\section{The Property Tax as a Capital Tax: A Room with Three Views}

In marked contrast, Fischel argues that zoning, when defined comprehensively to include all of its many facets listed above - rather than only readily quantifiable restrictions such as minimum lot size - is in fact a binding constraint in many instances. He notes that local regulators have considerable flexibility in defining and enforcing zoning regulations, and are limited to only a relatively small extent by the legal restrictions associated with various court decisions regarding fiscal zoning.

Unfortunately, all of the arguments on the specific issue of whether zoning constraints are binding (rather than on the simpler but much less informative issue of whether a huge number of zoning restrictions exists), are quite speculative in that they are based largely on anecdotal evidence. It seems clear that communities often successfully use zoning regulations to limit or exclude a wide variety of activities that they deem undesirable, and that zoning regulations can thus have important effects on home values and should thus not be viewed as mere "window dressing." Nevertheless, these results do not demonstrate that zoning is binding in terms of establishing minimum property values. More compelling evidence, however, will be difficult to come by, as it would literally require a detailed property-by-property study to determine the extent to which the combination of various zoning requirements in a jurisdiction, including variances and re-zonings in response to homeowner requests, results in binding constraints on its housing stock.

Finally, Ross and Yinger also stress that the existence of zoning is consistent not only with the benefit view, but also with several alternative models of housing and local public goods determination. Most importantly, zoning restrictions may simply ratify the nature of development that would occur in any case as a result of market forces, within the context of bidding/sorting models of community development. ${ }^{13}$ Thus, the existence of zoning does not prove the validity of the benefit view. ${ }^{14}$

13 For example, see Henderson (1977) and Wheaton (1993).

14 In addition, Fischel (1992) argues that studies that demonstrate that zoning tends to increase the prices of existing homes are consistent with the notion of binding fiscal zoning (although he notes that other explanations 


\section{The Property Tax as a Capital Tax: A Room with Three Views}

\section{Aggregate Budget Balance}

Another point often made in support of the benefit view is that there are powerful forces that act to prevent, in the words of Fischel (1992, p. 171) "wholesale free riding on local public goods." This point is an entirely reasonable one. It seems clear that fiscal zoning (broadly defined) can have an important influence on the nature of community development, especially in the form of precluding entry by low income households that would place high demands on local public services while providing little in the way of property tax base. ${ }^{15}$ Similarly, Fischel is correct when he argues that the current residents of a political jurisdiction have a clear and strong incentive to insist that new developments "pay their own way" in the form of paying enough taxes to cover the costs of their public services, so as not to impose an additional property tax burden (and thus lower property values) on existing residents.

However, once again, these phenomena are not inconsistent with the capital tax view of the property tax. Although fiscal zoning may very well change the character of the composition of a community, all that is required for the capital tax view to be operative is that the resulting communities not be zoned so precisely as to preclude the reductions in housing consumption predicted by the increase in the cost of capital attributable to the existence of, or increases in, the property tax. Moreover, capital tax view models are characterized by local government budget balance; thus, the capital tax view naturally does not imply any cross-subsidization across jurisdictions. Rather, local taxes and expenditures are equal — but at a lower than efficient level since local governments underspend on local public services in anticipation of tax-induced reduction in their property tax bases due to capital out-migration.

A similar phenomenon operates under the capital tax view for new development within an existing jurisdiction. The Tiebout-Hamilton models assume that local public services are publicly provided private goods; that is, there are no economies of scale in the provision of local public services. Facing the same property tax rate and thus the same cost of capital as existing properties, new developments will be characterized by the same less-than-efficient level of

could be offered as well). In any case, as stressed by Ross and Yinger (2000), the theoretical implications of zoning for existing house prices are unclear, as is the empirical evidence on this issue.

15 Note again, however, that other models — especially the bidding and sorting models noted above — also imply income segregation. 


\section{The Property Tax as a Capital Tax: A Room with Three Views}

housing and public expenditures; however, the property taxes paid will be sufficient to cover the cost of providing services to the new development. Under the capital tax view, the new development is basically a replica of the existing community — characterized by the same suboptimal levels of housing consumption and public service levels, but also by "budget balance” in the sense that the increase in taxes attributable to the development equals the costs of providing it with public services.

In addition, as described above, under the "single taxing jurisdiction" version of the capital tax view, not only are statutory payments of the property tax equal to expenditures but more importantly, the economic incidence of the tax also tends to be borne by local households. That is, although an increase in property taxation by a single jurisdiction - and, by extension, a new development in an existing jurisdiction - is borne by all capital owners in the nation, the economic effects of the tax-induced outflow of capital imply that local factors and consumers bear a burden equal to the full amount of the tax as well. In this sense, as stressed above, the capital tax view of the property tax includes an important "benefit" component (even though the tax is not a non-distortionary benefit tax as viewed by Hamilton and Fischel) and new developments "pay their own way."

\section{Interjurisdictional Capitalization}

Ever since the path-breaking article by Oates (1969), a large number of researchers have examined the capitalization into house prices of interjurisdictional differences in property taxes burdens and local expenditures. Although definitive evidence of such capitalization is difficult to establish, the current consensus seems to be that full capitalization is to a first approximation a reasonable assumption; see Dowding, John and Biggs (1994) for a recent survey, and Yinger, Bloom, Borsch-Supan and Ladd (1988) for a comprehensive study of property tax capitalization.

There is, however, no consensus about the implications of this evidence. There is general agreement that capitalization indicates that households value a relatively attractive combination of taxes and public services and will have greater demands for housing in communities in which they can obtain such a combination. Oates initially took this logic one step further and argued that capitalization was evidence for the Tiebout model and the benefit view. Similarly, as noted 


\section{The Property Tax as a Capital Tax: A Room with Three Views}

earlier, Fischel (forthcoming) argues that fiscal "capitalization is everywhere" and that such capitalization is sufficient to make the property tax a benefit tax at the local level.

However, as emphasized initially by Edel and Sclar (1974) and Hamilton (1976b) and more recently by Ross and Yinger (2000), capitalization does not imply the validity of the Tiebout model and the benefit view. Indeed, these authors argue that if the supply of communities is elastic in the sense that there are possibilities for new community formation (or changes in the boundaries of existing communities) or changes in the fiscal policies of existing communities, then the Tiebout model should in the long run imply zero capitalization. For example, in the context of the Hamilton (1975) model of homogeneous communities, housing prices should reflect only construction costs; property taxes paid just equal benefits received and thus have no independent effect on housing prices, just as housing prices are not affected by differences in expenditures on private goods. ${ }^{16}$ As stressed by Ross and Yinger, empirical analyses of housing prices across jurisdictions thus should not pick up any capitalization effects whatsoever if the economy is in a Tiebout-Hamilton type of equilibrium. They stress (p. 2016) that rather than providing support for the benefit view, "Statistically significant capitalization of S (services) or $\mathrm{t}$ (taxes) therefore serves as a rejection of the Hamilton model." Similarly, Edel and Sclar argue that decreases over time in the extent to which capitalization is observed indicate movement toward a Tiebout equilibrium (rather than declining importance of the Tiebout mechanism), and Rubinfeld (1987, p. 593) concludes that "in the long run, capitalization is likely not to occur.”

The implications of the existence of fiscal capitalization for the validity of the benefit view are thus unclear. The conditions required for the result of zero capitalization under a full Tiebout equilibrium are stringent and unlikely to be met in practice; in particular, the supply of communities to a metropolitan area is not highly elastic, jurisdictional boundaries are not flexible ${ }^{17}$ and, as argued by Hamilton (1983), the expansion of fiscally advantaged housing will always be opposed by existing residents who fear its negative effect on the values of existing

16 Hamilton (1976b) notes that this argument must be qualified by any fiscal advantages of industrial capital, differences in state or federal aid, and differential costs of providing local public services due either to differences in input costs or differences in the costs of providing services of a given quality attributable to differences in population characteristics across communities. 


\section{The Property Tax as a Capital Tax: A Room with Three Views}

properties. Hamilton concludes that capitalization thus provides evidence of the validity of the Tiebout mechanism and that the property tax is a benefit tax. However, others have argued that the link between capitalization and the benefit is unclear, so that empirical evidence confirming the existence of capitalization does not provide definitive evidence either for or against the benefit view. 18

More fundamentally, even if one accepts the idea that the benefit view implies fiscal capitalization, the implications of such capitalization for the choice between the benefit and capital tax views are ambiguous because some capitalization is also consistent with the capital tax view. Specifically, the "single jurisdiction" or "two burden" derivation of the capital tax view implies that any increase in local property taxes will be borne not only by capital owners nationwide, but also in a roughly equal amount by local factors of production and consumers. Thus, to the extent that this burden falls on local land owners - as is likely to occur if individuals are mobile across competing jurisdictions - the capital tax view implies that some of the burden of a local property tax increase will be capitalized into lower land prices. Similarly, the average burden of high property taxes in a jurisdiction, relative to the average national level of property taxation, may be capitalized into lower land prices. Thus, the existence of capitalization does not by itself distinguish between the benefit and capital tax views. One potential area for future research would be to construct models of the different capitalization processes and amounts capitalized under both views and then attempt to identify econometrically which view is more consistent with the resulting estimates. However, given the problems associated with estimating capitalization accurately, such an approach would be rather difficult to implement.

\section{Intrajurisdictional Capitalization}

The extent of intrajurisdictional capitalization provides another potential test of the effects of the property tax. The capitalization of fiscal differentials - the present value of the differences between benefits received and taxes paid — is the force behind the heterogeneous community

17 See Epple and Romer (1989).

18 For example, see Epple (1980), Wales and Wiens (1974), Brueckner (1979) and Epple, Zelenitz and Visscher (1978). 


\section{The Property Tax as a Capital Tax: A Room with Three Views}

version of the benefit view derived in Hamilton (1976a). Although there is much less empirical evidence on the extent of intrajurisdictional capitalization, Yinger, Bloom, Borsch-Supan and Ladd (1988) conclude that the available studies suggest a fair degree of capitalization. Thus the relevant question is whether full capitalization allows one to distinguish between the capital tax and benefit views. However, the answer is once again largely negative.

The various derivations of the capital tax view consider only interjurisdictional tax differentials. However, in the context of heterogeneous communities, any the tax-induced changes in land values that occur due to the excise tax effects under the capital tax view would apply only to average land values within the jurisdiction - which are in fact independent of the extent of housing heterogeneity in the Hamilton (1976a) heterogeneous communities model. Given these changes in average land values within a jurisdiction, capitalization of intrajurisdictional fiscal differentials would be consistent with the capital tax view, and would indeed be expected as long as households were perfectly mobile and homogeneous communities were available, as assumed in the Hamilton derivation. That is, as argued by Mieszkowski and Zodrow (1989), under these circumstances, such intrajurisdictional “excise tax” effects of the property tax would be expected to be capitalized into property values. For example, high income housing in a heterogeneous community, which would face a high tax burden for a given level of services relative to that in a homogeneous high income housing community, would sell at a discount. Similarly, low income housing in a heterogeneous community, which would face a low tax burden for a given level of services, relative to the homogeneous low income community, would sell at a premium. 19 These effects are analogous to those occurring under the heterogeneous community version of the benefit view (although the level of the capital stock and the quantity of public services provided would be lower under the capital tax view). Thus, evidence supporting intrajurisdictional capitalization does not help distinguish between the capital tax and benefit views.

19 Note, however, that such a situation, which corresponds to the case considered by Hamilton (1976a), is not a long run equilibrium, unless there is some mechanism to restrict developers from razing high income housing and replacing it with low income housing. For discussions of this point, see Dyer and Maher (1979) and Hamilton (1979). 


\section{The Property Tax as a Capital Tax: A Room with Three Views}

The discussion thus far suggests that, because the differences between the "benefit tax" aspects of the capital tax and benefit views are not as great as one might think, it is rather difficult to distinguish empirically between the two views of the property tax, and that several arguments often made in support of the benefit view do not provide compelling evidence in its favor. Nevertheless, several empirical tests are able to distinguish between the two views, and these are discussed in the following two sections.

\section{The Effects of Property Tax Differentials on Capital Intensity}

The different effects on capital intensity (capital-land ratios) implied by the capital tax and benefit views of the property tax provide one potentially effective means of distinguishing between them. The capital tax view implies that relatively high levels of property taxation should drive mobile capital out of a jurisdiction, resulting in lower capital intensity. By comparison, under the benefit view, the property tax functions as a user charge for services received so that capital intensity should be independent of the level of property taxation. In addition, under the capital tax view, capital outflow from a relatively high tax jurisdiction results in lower land and property values. In contrast, under the benefit view, a relatively high property tax rate in a community should not affect aggregate land and property values as it merely reflects a relatively high level of local public services.

Wassmer (1993) draws on these different implications of the capital tax and benefit views to conduct an intriguing empirical test of the validity of the capital tax view. Specifically, he examines a sample of 62 cities to see whether the effects of property tax differentials, relative to the average level of taxation for the sample, are consistent with the capital tax view in that a relatively high property tax rate in a city (1) depresses its property values, and (2) reduces its capital intensity. Wassmer finds evidence that supports the capital tax view; however, the effects are fairly modest as a one percent tax differential reduces property values by 0.13 percent and causes a very slight outflow of capital over a five-year period. He concludes (p. 154) that his results "provide evidence that local property taxes affect local property values in the manner predicted by the New View and are not possible under a pure Benefit View of property taxation.” His results — which are consistent with the conjectures of Mieszkowski (1972) — suggest significant forward shifting of property tax differentials into higher housing prices rather than reduced property values. However, they also indicate rather little in the way of the 


\section{The Property Tax as a Capital Tax: A Room with Three Views}

reallocation of housing capital that is essential to the operation of the capital tax view in the long run.

Wassmer's results thus provide some support for the capital tax view, but are far from definitive. One problem with his analysis is that his measure of the capital stock in a jurisdiction — the number of homes, with some fairly imprecise controls (e.g., the number of rooms and the extent of plumbing) for the amount of capital utilized in the homes — is sufficiently imprecise that his estimates are difficult to interpret. Moreover, proponents of the benefit view typically argue that it applies primarily in suburban jurisdictions - not the sample of central cities analyzed by Wassmer. Thus, a fruitful line for future research would be to extend Wassmer's work to a sample of suburban jurisdictions using more accurate measures of the capital stock in each jurisdiction.

\section{The Effects of Property Tax Differentials on Housing Rents}

The capital tax and benefit views of the property tax also have potentially different and thus testable implications for rental housing. In general, under the benefit view, one would expect an increase in property taxes to be reflected in an increase in housing rents, as long as the benefits received by renters equal the cost of the services being financed, as should occur in a TieboutHamilton equilibrium. By comparison, under the capital tax view, the effect of property tax finance of local expenditures received by renters is unclear. As described above, an increase in property taxes on rental properties by a single jurisdiction can be reflected in either higher rents or lower returns to landlords, depending on the relative elasticities of demand and supply of rental housing. Thus, forward shifting of the tax into higher rents is consistent with both views and would be inconclusive in terms of choosing between the capital tax and benefit views, but backward shifting to landlords should occur only under the capital tax view.

In a provocative recent contribution to the literature, Carroll and Yinger (1994) use this strategy to analyze the effects of the property tax for a sample of 147 towns and cities in the Boston metropolitan area. They argue that the previous literature on the extent of forward shifting of the property tax is inconclusive, as the results obtained are very mixed. Moreover, these studies suffer from a variety of methodological problems, which Carroll and Yinger detail and address in their research. Their results are consistent with the capital tax view, as landlords bear a large 


\section{The Property Tax as a Capital Tax: A Room with Three Views}

fraction of a property tax increase in all of the various cases they study (with different assumptions regarding the supply and demand elasticities of rental housing and different assumptions about renter mobility); the average burden on landlords varies from 84-91 cents per dollar of increased taxes and a minimum burden over all cases and all communities of 67 cents per dollar. In addition, the authors simulate the average burden of the property tax in their initial equilibrium and find that on average landlords bear 45 percent of existing tax differentials. Carroll and Yinger (1994, p. 311) conclude that, for their sample, "the property tax on rental housing is far short of being a benefit tax.”

As the most recent and most careful study of the extent of shifting of property taxes into higher rents, the Carroll and Yinger study provides strong support of the validity of the capital tax view, at least as it applies to rental housing. However, it does not preclude an equilibrium where the benefit view applies for suburban homeowners (as is most often asserted by proponents of the benefit view) even if it is invalid for renters.

More generally, although the two studies described above provide limited support for the capital tax view, considerable differences still exist regarding the extent to which the empirical literature distinguishes between the two views of the incidence of the property tax. For example, Ross and Yinger (2000, p. 2043) argue that "the evidence against the benefits view is overwhelming.” By comparison, Oates (1994, p. 142) concludes that, “As things stand, it is impossible to reject either the new view or the benefits view in favor of the other.”20

\section{Conclusion}

This article has reviewed the ongoing debate regarding the validity of the traditional, capital tax and benefit views of the local property tax. The capital tax view was shown to include the

20 Note, however, that the voluminous "tax competition" literature - mentioned above and reviewed in a recent article by Wilson (1999) — can be construed as providing evidence in support of the capital tax view. This literature examines the idea, noted above, that local jurisdictions, concerned about the outflow of capital to other jurisdictions associated with the use of a tax on mobile capital, will tend to reduce their reliance on the property tax and underprovide public services. The mere size of the this literature provides indirect support for the capital tax view; that is, if most observers subscribed to the benefit view of the property tax, the concerns of the tax competition literature regarding underprovision of services financed with property taxes on mobile capital would be largely irrelevant. 
The Property Tax as a Capital Tax: A Room with Three Views

traditional view as a special case, and to have some important characteristics that are typically associated with the benefit view. In particular, from a local perspective, the capital tax view predicts that local residents will tend to bear the full burden of an increase in the property tax (as predicted under the benefit view). One implication of the similarity between the capital tax and benefit views is that it is difficult to distinguish between them empirically, although several recent studies provide limited support for the capital tax view. At the same time, the differences between the two views are substantial. In particular, the capital tax view concludes that the property tax distorts the allocation of capital, including especially housing capital (and also distorts the level of local public services), while the benefit view argues that the property tax is a non-distortionary head tax. From a national perspective, the capital tax view concludes that the property tax is a tax on capital and is thus quite progressive, while the benefit view argues that the tax involves no redistribution. Thus, a resolution of this longstanding debate is critical to an understanding of the allocative and distributional effects of the local property tax. However, much further empirical investigation must be done before the validity of either view can be established definitively. 


\section{The Property Tax as a Capital Tax: A Room with Three Views}

\section{References}

Aaron, Henry J., Who Pays the Property Tax? Washington, D.C.: Brookings Institution, 1975.

Bradford, David F., "Factor Prices May Be Constant but Factor Returns Are Not," Economics Letters, 1978, 1:199-203.

Brown, Harry G., The Economics of Taxation. New York: Holt, 1924.

Brueckner, Jan K., "Property Values, Local Public Expenditure, and Economic Efficiency," Journal of Public Economics, 1979, 2: 223-246.

Carroll, Robert and John Yinger, "Is the Property Tax a Benefit Tax? The Case of Rental Housing,” National Tax Journal, 1994, 47: 295-316.

Dowding, Keith, Peter John and Stephen Biggs, “Tiebout: A Survey of the Empirical Literature,” Urban Studies, 1994, 31:767-797.

Dyer, James C., IV, and Michael D. Maher, “Capitalization of Intrajurisdictional Differences in Local Tax Prices: Comment,” American Economic Review, 1979, 69: 481-484.

Edel, Mathew and Sclar, Elliott, "Taxes, Spending, and Property Values: Supply Adjustment in a Tiebout-Oates Model," Journal of Political Economy, 1974, 82:941-954.

Ellickson, Bryan, “Jurisdictional Fragmentation and Residential Choice,” American Economic Review 1971, 61: 334-339.

Epple, Dennis, "What Do Tests of Capitalization Show?" Working Paper, Carnegie-Mellon University Graduate School Industrial Admininstration, Sept. 1980.

Epple, Dennis and Romer Thomas, 1989, “On Flexible Municipal Boundaries,” Journal of Urban Economics, 26: 307-319.

Epple, Dennis, Zelenitz, Allan and Visscher, Michael, "A Search for Testable Implications of the Tiebout Hypothesis," Journal of Political Economy, 1978, 88: 405-426.

Fischel, William A., "Fiscal and Environmental Considerations in the Location of Firms in Suburban Communities," in Fiscal Zoning and Land Use Controls, in Edwin S. Mills and Wallace E. Oates (eds.), Lexington, MA: Lexington Books, 1975, pp. 119-173.

Fischel, William A., "Is Local Government Structure in Large Urbanized Areas Monopolistic or Competitive?” National Tax Journal, 1981, 34: 95.

Fischel, William A., The Economics of Zoning Laws: A Property Rights Approach to American Land Use Controls, Baltimore: Johns Hopkins University Press, 1985.

Fischel, William A., Regulatory Takings: Law, Economics, and Politics, Cambridge, MA: Harvard University Press, 1995. 


\section{The Property Tax as a Capital Tax: A Room with Three Views}

Fischel, William A., "Property Taxation and the Tiebout Model: Evidence for the Benefit View from Voting and Zoning,” Journal of Economic Literature, 1992, 30: 171-177.

Fischel, William A., "Municipal Corporations, Homeowners, and the Benefit View of the Property Tax," in Wallace E. Oates (ed.), Property Taxation and Local Government Finance, Cambridge: Lincoln Institute of Land Policy, forthcoming. Appeared in State Tax Notes, Volume 18, No. 22 (May 22, 2000), pp. 1781-1803.

Fischel, William A., "Homevoters, Municipal Corporate Governance, and the Benefit View of the Property Tax,” National Tax Journal, 2000, 54: 157-174.

Hamilton, Bruce W., "Zoning and Property Taxation in a System of Local Governments," Urban Studies, 1975, 12: 205-211.

Hamilton, Bruce W., "Capitalization of Intrajurisdictional Differences in Local Tax Prices," American Economic Review, 1976a, 66: 743-753.

Hamilton, Bruce W., "The Effects of Property Taxes and Local Public Spending on Property Values: A Theoretical Comment," Journal of Political Economy, June 1976b, 84: 205211.

Hamilton, Bruce W., "“Capitalization of Intrajurisdictional Differences in Local Tax Prices: Reply,” American Economic Review 1979, 69: 485.

Hamilton, Bruce W., "A Review: Is the Property Tax a Benefit Tax?" in Local Provision of Public Services: The Tiebout Model after Twenty-five Years, in George R. Zodrow (ed.), New York: Academic Press, 1983, pp. 85-107.

Harberger, Arnold C., “The Incidence of the Corporate Income Tax,” Journal of Political Economy 1962, 70: 215-240.

Henderson, Vernon J., Economic Theory of the Cities, New York: Academic Press, 1977.

Kotlikoff, Laurence J. and Summers, Lawrence H., "Tax Incidence," in Handbook of Public Economics, in Alan J. Auerbach and Martin S. Feldstein (eds.), Amsterdam: North Holland, 1987, pp. 1043-1092.

Ladd, Helen F., Local Government Tax and Land Use Politics in the United States, Northhampton MA: Edward Elgar Publishing, 1998.

Lin, Chuan, "A General Equilibrium Analysis of Property Tax Incidence," Journal of Public Economics, 1986, 29: 113-132.

McLure, Charles E., Jr., "The New View of the Property Tax: A Caveat," National Tax Journal, 1977, 30: 69-76.

Mieszkowski, Peter, "The Property Tax. An Excise Tax or a Profits Tax?" Journal of Public Economics, 1972, 1: 73-96. 


\section{The Property Tax as a Capital Tax: A Room with Three Views}

Mieszkowski, Peter and Zodrow, George R., “The Incidence of a Partial State Corporate Income Tax,” National Tax Journal, 1985, 38: 489-496.

Mieszkowski, Peter and Zodrow, George R., "Taxation and the Tiebout Model: The Differential Effects of Head Taxes, Taxes on Land Rents, and Property Taxes,” Journal of Economic Literature, 1989, 27, 1098-1146.

Netzer, Dick, Economics of the Property Tax, Washington DC: Brookings Institution, 1966.

Oates, Wallace E. "The Effects of Property Taxes and Local Public Spending on Property Values: An Empirical Study of Tax Capitalization and the Tiebout Hypothesis," Journal of Political Economy, 1969, 77: 957-961.

Oates, Wallace E., “Federalism and Government Finance,” in John S. Quigley and Eugene Smolensky (eds.), Modern Public Finance, Cambridge MA: Harvard University Press, 1994.

Ross, Stephen and John Yinger, "Sorting and Voting: A Review of the Literature on Urban Public Finance,” in Handbook of Regional and Urban Economics, Vol. 3, Paul Cheshire and Edwin S. Mills (eds.), Amsterdam: North Holland, 2000.

Rubinfeld, Daniel L., "The Economics of the Local Public Sector," in Handbook of Public Economics, in Alan J. Auerbach and Martin S. Feldstein (eds.), Amsterdam: North Holland, 1987, pp. 571-645.

Simon, Herbert A., “The Incidence of a Tax on Urban Real Property,” Quarterly Journal of Economics, 1943, 59: 398-420.

Tiebout, Charles M., "A Pure Theory of Local Expenditures," Journal of Political. Economy, 1956, 64: 416-424.

Wales, T. J. and Weins, E.G., "Capitalization of Residential Property Taxes: An Empirical Study," Review of Economic Statistics, 1974, 56: 329-333.

Wassmer, Robert W., "Property Taxation, Property Base, and Property Value: An Empirical Test of the "New View", National Tax Journal, 1993, 46: 135-160.

Wheaton, William C., "Land Capitalization, Tiebout Mobility, and the Role of Zoning Regulations,” Journal of Urban Economics, 1993, 34: 102-117.

White, Michelle J., "Firm Location in a Zoned Metropolitan Area," in Fiscal Zoning and Land Use Controls, in Edwin S. Mills and Wallace E. Oates (eds.), Lexington, MA: Lexington Books, 1975, pp. 175-202.

Wildasin, David E. Urban Public Finance. New York: Harwood, 1986.

Wilson, John D. "A Theory of Inter-Regional Tax Competition," Journal of Urban Economics, 1986, 19: 296-315. 
The Property Tax as a Capital Tax: A Room with Three Views

Wilson, John D., “Theories of Tax Competition,” National Tax Journal, 1999, 52: 269-304.

Yinger, John, Bloom, Howard S., Boersch-Supan, Axel, and Ladd, Helen F. Property Taxes and House Values: The Theory and Estimation of Intrajurisdictional Property Tax Capitalization, San Diego, CA.: Academic Press, 1988.

Zodrow, George R., "The Tiebout Model After Twenty-Five Years: An Overview," in Local Provision of Public Services: The Tiebout Model After Twenty-Five Years, in George R. Zodrow (ed.), New York: Academic Press, 1983, pp. 1-16.

Zodrow, George R., "Reflections on the New View and the Benefit View of the Property Tax," in Wallace E. Oates (ed.), Property Taxation and Local Government Finance, Cambridge: Lincoln Institute of Land Policy, forthcoming. Appeared in State Tax Notes, Volume 18, No. 22 (May 22, 2000), pp. 1805-1821.

Zodrow, George R. and Mieszkowski, Peter, "The Incidence of the Property Tax. The Benefit View vs. the New View," in Local Provision of Public Services: The Tiebout Model after Twenty-five Years, in George R. Zodrow (ed.), New York: Academic Press, 1983, pp. 109-129.

Zodrow, George R. and Mieszkowski, Peter, "The New View of the Property Tax: A Reformulation," Regional Science and Urban Economics, 1986a, 16: 309-327.

Zodrow, George R. and Mieszkowski, Peter, "Pigou, Tiebout, Property Taxation and the Underprovision of Local Public Goods," Journal of Urban Economics, 1986b, 19: 356-370. 